\title{
PENTRU O POETICĂ A RITMURILOR DISCURSIVE ÎN LIRICA BLAGIANĂ
}

\section{Mihai Duma, masterand Universitatea „Babeș-Bolyai” - Cluj-Napoca}

\begin{abstract}
Lucian Blaga's writing merges into the boundaries of the European modernism both if we refer to the formal and the theoretical aspects of his work. His poetry shows us the deconstruction of the typical rhymed verse through the use of the white one. But as soon as poetry deconstructs the concepts of rhyme or meter as a necessity to define the formal aspects of writing, there is the resistant concept of rhythm which shows himself a plural concept. The aim of this paper is to investigate rhythm in the poetical creation of Lucian Blaga not as the asset of formal constructions, but as it was proposed by Henri Meschonnic a discursive rhythm which is in a tight relation with the subject of speech.
\end{abstract}

Key-words: historical forms of writing, white verse, discursive rhythm, subject, poetics;

\section{Ritmul - de la metrică la sens istoric}

În Lecțiile de poetică structurală, Iuri Lotman considera ritmul ca „repetarea ciclică a unor elemente diferite în poziții identice, făcută în scopul de a se asimila entități diferite sau a se dezvălui asemănătorul în divers, fie repetarea similarului cu scopul de a se dezvălui caracterul aparent al similitudinii, de a se stabili diferența în asemănător” (Lotman, 1970: 89 - 90). Conform premiselor sale de definire a ritmului, în spaţiul poeziei, cuvintele se găsesc (sau nu) pe niveluri de echivalență semantică în funcție de izometrismul lor, astfel încât, se creează un ansamblu ierarhizat de corespondențe translingvistice, deoarece opera poetică s-ar caracteriza prin recurență ca element structurant. Perspectiva lui Lotman asupra ritmului vizează formele poetice ce propun un tipar metric artificial și exterior, dacă ipoteza teoreticianului se confirmă sau nu, rămâne de discutat. Întrebarea care se ridică nu vizează atât validitatea definiției în relație cu formele fixe, ci dacă ea poate fi universalizată în modernitate, de vreme ce, în istoria tiparelor poetice, forma liricii este într-o perpetuă căutare de sine, după cum o ilustrează cazul versului liber.

Versul liber reliefează în devenirea formelor poetice caracterul istoric și polemic al tabularității discursului poetic: „Caracterul polemic aparține fiecărei forme, care este cu necesitate, din punct de vedere istoric, o contra formă” (Meschonnic, 1982: 601). Părăsirea sistemelor metrice tradiționale în favoarea versului liber ilustrează continua transformare formală în domeniul poeziei, marcând istoricitatea oricărui tipar. Absența schemelor metrice nu

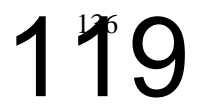


plasează versul liber în afara poeticității, ci doar îl sustrage definirii sale în funcție de ,proprietățile generale relative la structura sa internă, fie ele ritmice sau sintactice" (Murat, 2005: 382). Tabularitatea poemului devine indicele poeticităţii, segmentarea fiind marcată prin intermediul convenției tipografice.

Individualizarea versului liber în domeniul poeziei reflectă atât istoricitatea formelor, cât și trăsătura acestora de constructe culturale, având caracter semnificant. Analiza critică pe care Henri Meschonnic o dedică ritmului evidențiază caracterul de construct cultural al metricii ce se integrează ca element semnificant în cultura iudeo-creștină. „Metrica spațializează limbajul, înscriindu-i muzica. În abstracția metrică, silabele sunt egale, nu au decât o valoare de poziție codată. În discurs, ele [silabele n.a.] nu sunt de aceeași factură. Există reguli metrice. Nu există ritm [ca urmare a metricii în discursul poetic n.a]. Metrica măsoară. Ritmul, care ia parte la riscul și necunoscutul unui discurs, nu se măsoară. El se analizează în termeni de discurs, care nu țin doar de fonetică. Metrica este imaginară" (Meschonnic, 1982: 528). Astfel, unităţile metrico-prozodice se relevă în calitatea lor de constructe culturale, fiind asociate unui imaginar muzical, ce percepe rostirea poetică ca o încercare de recuperare a limbajului originar, totodată, asociinduse binarității semnului lingvistic, schemele poetice primesc caracter semnificat. Dar ritmul poetic nu survine ca urmare a unor strategii de artificiu formal, ci se manifestă în discurs unde se instituie printr-un raport istoric de interdependență între subiect și limbaj. În această viziune, ritmul nu rămîne apanajul tiparelor prozodice, nu este un semn caracterizat prin biplaneitate; implicând subiectul în afara căruia sensul nu poate exista, ritmul este un sistem ce, prin istoricitatea sensului, poate fi numit o formă-subiect.

Posibilitatea de a realiza o istorie culturală a individualizării formelor discursului poetic presupune ,istoricitatea subiectivă a discursului” (Ibidem: 603). Versul liber deconstruiește tiparele de creație, el nu poate fi judecat după legile metricii ce presupun spre spaţializare o serie de structuri numerice. Ritmul discursiv nu este generat de variația simetrică a elementelor fonice, căci nu există identitate între muzicalitate (generată de scheme prozodice) şi ritmul lingvistic ca sistematizare în actul discursiv a ceea ce este în perpetuă mișcare.

Ritmul ca devenire istorică, ca manifestare a subiectului în discurs, are ca punct de plecare analiza semantico-istorică pe care Benveniste o realizează, pornind de la etimologia conceptului: ,se referă la formă în momentul în care e imprumutată de ceva mişcător, mobil, fluid, forma a ceea ce nu are consistență organică: se potrivește cu cu pattern-ul unui element fluid, unei litere modelate la întâmplare, unui peplos aranjat după bunul plac, dispoziției momentane a caracterului sau temperamentului" (Benveniste, 2000: 315). Din această perspectivă, ritmul nu reprezintă o subipostază a formei, el este mărturia devenirii ansamblului lingvistic. Dacă ritmul se situează în

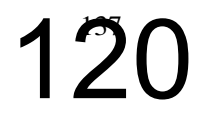


interiorul limbajului, în actul discursiv, ce presupune un raport de alteritate între subiect și limbaj și care conduce la producerea unui sens circumscris istoric, ritmul discursiv este indisolubil legat de sens: „Ritmul este organizarea sensului în discurs. Dacă este o organizare a sensului, nu mai este un nivel destinct, juxtapus. Sensul se face în şi prin toate elementele discursului. Ierarhia semnificatului nu mai este decât o variabilă, în funcție de discursuri, de situații" (Meschonnic, 1982: 70). La nivelul discursului, elementele presemnificate ce intră în generarea sensului sunt plasate pe acelaşi nivel de semnificare, fiecare dintre ele se concretizează ca semnificanți. În acest mod, sunt anulate distincțiile monadice și ierarhizate în construirea sensului impuse de către domeniul limbii, precum morfologia, fonetica, sintaxa.

Definiţia pe care Benveniste o propune ritmului nu ocultează subiectul: „aranjat după bunul plac, al dispoziției momentane”, discursul devine ,activitatea unui subiect în și împotriva unui subiect, a unei culturi, a unei limbi - care nu este niciodată decât discurs [...] Ritmul ca organizare a discursului, deci, a sensului, reașează în prim-plan că nu există sens decât prin şi pentru subiecți” (Ibidem: 71). Sensul nu se găsește în interiorul limbii, nu reprezintă un dat transcendent, ci este produs doar în interiorul discursului, prin intermediul subiecților. Planul limbii va fi supus unei continue deteritorializări în interiorul discursului, istoric vorbind, elementele semnificante trasează raporturi variabile în funcție de mediul interior al afectelor și cel exterior, contextual. „Dacă sensul este o activitate a subiectului, și ritmul este o organizare a sensului în discurs, ritmul este cu necesitate o organizare sau o configurare a subiectului in propriul discurs. $O$ teorie a ritmului în discurs este, deci, o teorie a subiectului în limbaj" (Idem.). Doar considerând discursul ca fiind unitatea de generare a sensului putem propune o teorie a discursivității ce nu ignoră subiectul, acesta fiind produsul discusului, și, în același timp, în absența căruia nu se poate actualiza. Ritmurile care traversează teritoriile discursivității şi ale subiectivității asigură solidaritatea dintre limbaj și subiect, articularea sensului este urmarea unui raport de istoricitate. Sensul se așază în istorie, după cum istoria modifică sensurile.

În acest corp continuu al discursului, cercetarea domeniului nu se poate face prin retorică, căci aceasta se ocupă de segmentarități. Dacă discursul este o totalitate integrantă a pluralităților, domeniul trebuie supus unui travaliu al poeticii care „duce subiectul dincolo de ceea ce lingvistica și pragmatica pot face, spre o generalizare a subiectivității” (Meschonnic, 2006: 78). O poetică a ritmurilor care investighează raporturile istorice ale subiectului cu rostirea, plasarea sa în și construcția prin limbaj și raporturile pe care le întreține cu acesta. Sensul poeticului survine ca urmare a unei sistematematici a discursului în care eul se rostește pe sine și prin care se construiește, observând caracterul istoric al semanticii limbajului și raporturile pe care eul le are cu aceasta.

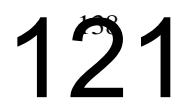




\section{O poetică discursivă a subiectului}

Pentru o poetică istorică a ritmului ca generator de sens în cadrul discursului și o analiză aplicată liricii, structurile discursului trebuie văzute ca o sistematizare a ritmurilor istorice ce străbat limbajul. Acesta se prezintă ca un prim palimsest, închizând în corpul său semnificant influențele culturale, sociale, filosofice, istorice. Discursul poeziei, prin subiectul rostitor, articulează sensul printr-o configurație a ritmurilor limbajului, generarea sensului nu mai este asociată tiparelor metrice fixe, ci tensiunilor ce străbat limbajul și istoria discursurilor și care își găsesc organizarea în rostirea poetică. Versul liber ca realizare formală vine spre a ilustra tocmai această variație a ritmurilor interne ale limbajului ce se manifestă la nivel poetic. Analiza poemelor în vers liber scrise de Lucian Blaga ilustrează limitările interne de către rimurile limbajului în generarea sensului, chiar şi în actul discursiv ce implică un subiect al enunțării ce contextualizează rostirea.

Poemul Vreau să joc! revalorizează, prin intertextualitate, lirica eminesciană, așezând subiectul care se rostește în raport cu interioritatea sa. Revalorizarea unui fragment anterior anterior ilustrează circulaţia în sfera discursivă. Modificarea fragmentului și refiguralizarea sa, prin integrarea în noul asamblaj de enunțare, ilustrează, conform viziunii lui Benveniste, ritmicitatea ce travesează limbajul. Reașezarea într-o nouă formă de figurare a hipotextului eminescian reflectă relația contextuală dintre subiectul care se rostește și construiește în discurs și generarea sensului poetic. Sensul survine ca urmare a unei relații sistemice între subiectul anistoric al enunțării, care își atinge statutul doar prin enunțare, și ritmicitățile limbajului, formele multiple pe care poate să le obțină prin individualizarea în discurs. Referința la Luceafărul - „Pământule, dă-mi aripi:/ săgeată vreau să fiu să spintec/ nemărginirea,/ să nu mai văd în preajmă decât cer,/ deasupra cer,/ și cer sub mine -/ și-aprins de valuri de lumină/ să joc/ străfulgerat de-avânturi nemaipomenite/ ca să răsufle liber Dumnezeu în mine/ să nu cârtească/ «Sunt rob în temniță!»” (Blaga, 2006: 12 - 13) - asociază zborul Lucefărului în spațiu cu interiorutatea eului. Elanul vitalist necesar descătuşării divinității din interiorul eului este figurat tocmai prin intertextualitate. De această dată, imaginea înălțării în cosmos este rasturnată spre o coborâre în adâncul ființei. Dacă în poemul eminescian scena prezinta elemente metrico-prozodice, de această dată, este turnată în forma versului liber. Istoricitatea discursului şi cea a formei se condiționează reciproc, fiind interdependente. În acord cu modernitatea poetică blagiană, versul liber devine forma scriiturii pentru generarea sensului poetic. Elementul figural al rostirii se desfăşoară diferit în funcție de contextul acesteia, subiectul blagian ilustrează o dimensiune a interiorităţii echivalentă dimensiunilor spațiului cosmic. Poemul eminescian aducea în prim-plan o ipostază a divinității a cărei imposibilitate se afla în a retrage darul nemuririi, pe când Vreau să joc! configurează o imagine a

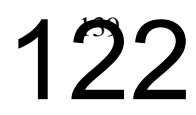


sacralității ca parte integrată a eului, motiv pentru care rostirea ipotetică a divinului este redată prin conjunctiv. Cu toate acestea, rămânând la nivelul de posibilă enunțare, afirmația nu poate fi atribuită decât eului și dorinței sale de acces deplin la propria subiectivitate.

Un alt poem în care discursul este actualizat sub forma versului liber este Liniște. La o analiză structurală a poemului acesta poate fi cu ușurință împărțit în două secvențe lirice referitoare la două modalități diferite de adresare ale discursului, fiecare dintre acestea fiind precedată de distihul ce deschide poemul. În ciuda faptului că se constituie în jurul temei logosului și a actualizărilor sale, poemul debutează printr-un distih ce încearcă să redea însăși absența rostirii. Ca tipar fix, distihul este „un ansamblu de două versuri cosecutive, alcătuind o strofă care trebuie să aibă singură înțeles deplin" (Bot, 2006: 219). Acest fapt îi asigură maxima concizie, unitate și caracterul aforistic. Dar încercarea de redare poetică a tăcerii eșuează tocmai datorită subiectului care se aşează în discurs, rostirea, fie ea și lirică, se instituie pe fundalul tăcerii pe care îl întrerupe: „Atâta liniște-i în jur de-mi pare că aud/ cum se izbesc de geamuri razele de lună" (Blaga, 2006: 26). Prima secvență, în dărătul dedublării eului și a temei thanatice, ascunde problematica rostirii și a ritmurilor istoricității ce străbat limbajul: „În piept/ mi s-a trezit un glas străin/ și-un cântec cântă-n mine un dor ce nu-i al meu./ Se spune, că strămoși, cari au murit fără vreme,/ cu sânge tânăr încă-n vine,/ cu patimi mari în sânge/ cu soare viu în patimi/ vin,/ vin să-și trăiască mai departe/ în noi/ viața netrăită" (Ibidem: 26 - 27). „Glasul străin” care se rostește este reprezentat ritmurile care parcurg ca intensități corpul istoric al limbajului. Secvența debutează printr-o rostire la mod personal, dar subiectul este martor la apariția vocii străine care conține pulsiuni revolute. Vocea, pătrunsă de ritmurile culturale, aparține limbajului și nu se poate articula în afara sa. Discursul devine unul impersonal - ,se spune” - vocea lirică fiind a subiectului, în subiect, dar străină sieși. Între cele două secvențe, se interpune distihul din începutul poemului, acesta nu are trăsăturile unui refren de natură metrico-prozodică, deoarece nu intervine în discurs la intervale de timp regulate, cu toate acestea cele două versuri reprezină o constantă pentru eul care se rostește, un refren intim, care este reprezentat de liniștea căreia i se opune și face posibil discursul poetic. Cea de-a doua secvență este conturată de adresarea subiectului către intimitatea sa, de fapt, o autoadresare: „O, cine știe - suflete'n ce piept îţi vei cânta/ și tu odată peste veacuri/ pe coarde dulci de liniște,/ pe harfă de'ntuneric - dorul sugrumat/ și frânta bucurie de vieață? Cine știe? Cine știe?” (Ibidem: 27). Motivul orfic al harfei demonstrează, încă o dată, problematizarea limbajului și a receptării discursului poetic. Subiectul blagian conștientizează contextualitatea și istoricitatea receptării discursului, iar proiecția cadrului conturat de liniște în viitor reprezită o încercare de a reface momentul prezent al rostirii. Discursul poetic este supus istoricității receptării, astfel, se

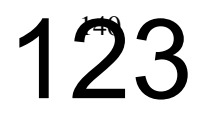


încadrează producției discursive, iar subiectul prin ritmurile limbajului se încadrează în această configurație istorică.

Dar munții - unde-s? este un alt poem ce arată prezența ritmurilor la nivelul discursului poetic, chiar dacă acestea nu sunt de factură metrică. Ultimele două strofe evidențiază traversarea poemului de ritmurile discursive, subiectul fiind factorul esențial pentru articularea sensului: „Dar munții unde-s? Munții,/ pe cari să-i mut din cale cu credința mea? // Nu-i văd,/ îi vreau, îi strig și - nu-s!” (Ibidem: 34). Referința intertextuală se realizează aici cu textul biblic, fundamental pentru viziunea culturii europene. Subiectul reia şi modifică textul scripturii, dacă Iisus era cel care le spunea apostolilor că, având credința cât un bob de muștar, ar reuși să mute munții, acum, interogațiile retorice sunt adresate de eu divintăţii. Discursul, imposibil de actualizat în absența subiectului, evidențiază, prin modificările aduse textului biblic, sistemul istoric pe care îl constituie împreună cu eul rostirii. Tema limbii adamice subîntinde discursul poetic, reflectând modul în care un text, cel testamentar, a structurat concepția asupra logosului. Ultimul vers - ,îi vreau, îi strig și - nu-s!" (Ibidem: 35) - prezintă eșecul subiectului și al rostirii poetice de a aduce în ființă prin numire. Discursul poetic este cel care subminează mitul opoziției dintre limbajul poetic și limbajul cotidian, căruia îl dezvăluie încercarea de a propune o viziune instrumentalizată limbajul. Observând ritmurile ce străbat limbajul, reciclarea discursurilor, înscrierea lor în istoricitate și solidaritatea contextuală cu subiectul enunțarii în cadrul discursului, apare ca evident că şi cotidianul e guvernat de acelaşi limbaj istoric și discursuri metaforizante.

Articulând sensul poetic plecând de la contrarii, poemul Lumina raiului reliefează generarea opozițiilor și a sinonimiilor în discursul poetic nu de la echivalența cuvintelor în plan metric, ci de la ritmurile istorice ce traversează corpul semnificant al limbajului și se materializează prin subiect, la nivel poetic: „Eu nu-mi am inima în cap,/ nici creeri n'am în inimă./ [...] Şi-ar înflori pe buza ta atâta vrajă,/ de n'ai fi frământată,/ Sfânto,/ de voluptatea ascunsă a păcatului?/ Ca un eretic stau pe gânduri și mă'ntreb:/ De unde-și are raiul -/ lumina? - Știu: Îl luminează iadul/ cu flăcările lui!" (Ibidem: 40 - 41). Sensul poetic este generat prin aşeazarea împreună a unor opoziții ideatice ce au marcat istoria culturii europene - pe de-o parte, raţiunea și afectul, pe de altă parte, binele și răul, după cum sunt ele sistematizate în creștinism. Organizarea tensiunii aparține subiectului care sistematizează ritmurile semanticii, pe când antiteza dintre termeni nu este creată pornind de la metrică, ci poate fi urmărită în istoria culturii. Limbajul își dezvăluie aici o caracteristică ironică ce îi este imanentă - posibilitatea de a crea sens la nivel discursiv, chiar conjugând împreună termeni cu o valoare semantică opusă. În plus, fiecare dintre termenii ce se găsesc într-un raport de tensiune, poartă în sine urma rostirilor anterioare, căci dacă la nivelul limbii cuvintele se află în

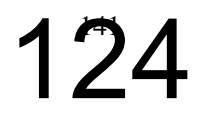


stare statică, discursul le pune în act. Ironia impurității limbajului se opune dogmatismului ce încearcă acreditarea unui limbaj apoetic transparent. Tocmai aici se observă rolul subiectului ca factor sistematizant al sensului, dacă discursul nu există în absența sa, și nici nu poate ajunge a statutul de subiect în afara rostirii, nici sensul nu poate fi articulat în absența subiectului.

\section{Concluzii}

O poetică istorică a ritmurilor ilustrează continuumul de sens, nu ne referim la un sens identic egal cu sine indiferent de momentul istoric, atemporal, ci, dimpotrivă, la modul în care poate fi urmărit sensul istoric al unui semn lingvistic în solidaritate cu un semnificant. Astfel la nivelul discursului poetic tensiunile care se identifică în limbaj nu sunt cauzate de pozițiile metrice echivalente, ci de ritmurile ce străbat corpul limbajului. Poezia cu vers liber a lui Lucian Blaga ilustrează importanța subiectului ca sistematizant al sensului în discus, întrucât, dacă nu există discurs fără subiect, nici sensul nu își găsește forma în absența sa. Sensul este condiționat istoric, la fel cum istoria se înscrie în sens modificându-l fundamental. Poemele blagiene ilustrează tensiunile palimpsetului lingvistic, articulându-le prin intermediul eului care se rostește în actul discursiv. Aflându-ne în acest continuum istoric ce se manifestă la nivelul limbajului poetic, prin analiza propusă, ritmul nu va mai fi ascuns de metrică și nici discursul de limbă. Poezia blagiană se înscrie prin sensurile sale istoriei culturii iudeo-creștine, fapt ce o arată ritmurile ce o parcurg și conduc la generarea sensului poetic.

\section{Bibliografie}

Benveniste, Émile, Probleme de lingvistică generală, vol I, trad. Lucia

Magdalena Dumitru, ed. Teora, București, 2000.

Blaga, Lucian, Poezii, Fundația regală pentru litaratură și artă, 2006.

Bot, Ioana, Sensuri ale perfecțiunii. Literatura cu formă fixă ca încercare asupra limitelor limbajului, Cluj - Napoca, Casa Cărții de Știință, 2006.

Lotman, Iuri, Lecții de poetică structurală, trad. Radu Nicolau, ed. Univers, București, 1970.

Meschonnic, Henri, Critique du rythme. Anthropologie historique du langage, Éditions Verdier, Lagrasse, 1982.

Meschonnic, Henri, La rime et la vie, Gallimard, Saint-Amand, 2006.

Murat, Michel, Le vers libre rimé în Poétique de la rime, editat de Michel Murat și Jacqueline Dangel, Éditions Champion, Paris, 2005. 